\title{
1 Characterization of EST derived SSRs from the bay scallop, Argopecten irradians
}

2 Steven Roberts, Christina Romano, and Gabriele Gerlach

3 Marine Biological Laboratory, Woods Hole, MA 02543

4

5 Abstract

6 Interest in bay scallop conservation has resulted in organized stock enhancement

7 efforts and increased attention to fisheries management issues. Genetic markers can

8 facilitate the monitoring of enhancement efforts, characterization of wild populations, and

9 optimize hatchery practices. We have identified eight polymorphic simple sequence

10 repeat markers including one dinucleotide repeat, six trinucleotide repeats and one

11 compound dinucleotide repeat, in expressed sequence tags generated from multiple bay

12 scallop cDNA libraries. The numbers of alleles range from $2-5$. The expected and

13 observed heterozygosities range from $0.093-0.720$ and $0.095-0.600$, respectively.

15 The bay scallop (Argopecten irradians) is found in the western North Atlantic

16 along the majority of the United States coast. The bay scallop is a hermaphroditic bivalve

17 mollusk with an enlarged, single adductor muscle that is able to quickly clasp both valves

18 together for propulsion. Commercial landings of bay scallops in the United States peaked

19 at over 1200 metric tons in 1982, corresponding to more than 11 million dollars (US) of

20 revenue (NMFS 2004). Over the past twenty years populations have experienced

21 significant declines that have been attributed to several factors including habitat loss and

22 pressure from commercial and recreational fisheries. One approach to enhance bay

23 scallop populations involves spawning wild broodstock in a hatchery and releasing 
24 offspring into the wild (Arnold 2001). The aim of this work was to identify genetic

25 markers that could be used in evaluating stock enhancement efforts. These same markers

26 will also aid in characterizing population dynamics of native populations and assist

27 aquaculture operations efficiently manage stocks.

28 In order to identify genetic markers, bay scallop expressed sequence tags (ESTs)

29 were screened for simple sequence repeats (SSRs). This approach has been used

30 successfully across several taxa, and is prevalent in the field of plant genomics (i.e.

31 Kantety et al 2002). To date, we have generated and submitted 2089 cDNAs to NCBI's

32 EST database from the bay scallop (Roberts et al. unpublished, Roberts and Goetz 2003).

33 These ESTs are from developing larvae as well as from adductor muscle and gonad

34 tissue. Simple sequence repeats were identified using the Simple Sequence Identification

35 Tool (http://www.gramene.org/db/searches/ssrtool) (Temnykh et al. 2001). Primers

36 flanking SSRs with a minimum of 5 tandem repeats and 14 bps were designed using

37 Macvector 7.2 (Accelrys) or by visual inspection.

38 DNA was isolated from mantle tissue of bay scallops collected from Cape Cod,

39 MA utilizing a Chelex (BioRad) extraction technique (Walsh et al, 1991). The PCR was

40 carried out under the following conditions: initial denaturation for $3 \mathrm{~min}$ at $94^{\circ} \mathrm{C}$ followed

41 by $30-40$ cycles of $1 \mathrm{~min}$ at $94^{\circ} \mathrm{C}, 1 \mathrm{~min}$ at $52-58^{\circ} \mathrm{C}$ according to the specific primer set

42 used (Table 1) and $1 \mathrm{~min}$ at $72^{\circ} \mathrm{C}$ with a final extension step of $7 \mathrm{~min}$ at $72^{\circ} \mathrm{C}$. PCRs

43 were carried out in a total volume of $18 \mu \mathrm{l}$ containing $0.2 \mu \mathrm{M}$ each of forward and

44 reverse primers, $0.2 \mu \mathrm{M}$ dNTPs (Invitrogen), $1.8 \mu 1$ 10X AmpliTaq Buffer containing 15

$45 \mathrm{mM} \mathrm{MgCl} 2$ (Applied Biosystems), $0.36 \mathrm{U}$ AmpliTaq DNA Polymerase (Applied

46 Biosystems), and $0.8 \mu$ DNA template. 
Electrophoresis of the PCR fragments was performed using the SEA 2000TM

48 advanced submerged gel electrophoresis apparatus (Elchrom Scientific AG, Switzerland).

49 Products and a 10 bp DNA Ladder (Invitrogen) were separated on Spreadex EL-400 or

50 EL-600 S-100 gels (Elchrom Scientific AG, Switzerland) at 95-150 V and $998 \mathrm{~mA}$ for

$51 \quad 30-45$ minutes at $55^{\circ} \mathrm{C}$; and visualized by staining with SYBR Gold. Alleles were scored

52 manually by visual inspection. The data were first analyzed using Micro-checker (van

53 Oosterhout, et al. 2004) for the presence of genotyping errors. Expected and observed

54 heterozygosities, and Fis values were calculated using FSTAT version 2.93 (Goudet

55 1995) (Table 1). Pairwise tests for linkage disequilibrium were also performed using

56 FSTAT. Sequencial Bonferroni corrections were applied for all multiple tests.

57 Primers were designed for 29 SSRs, of which 8 were not easily amplified, 13

58 were monomorphic, and 8 were polymorphic. The eight polymorphic SSRs identified

59 include one dinucleotide repeat, six trinucleotide repeats and one compound dinucleotide

60 repeat. The numbers of alleles range from $2-5$. The expected and observed

61 heterozygosities range from $0.093-0.720$ and $0.095-0.600$, respectively. The reduced

62 heterozygosity and departure from Hardy-Weinberg equilibrium at locus GL23, suggests

63 the presence of null alleles. Further, tests for null alleles using Micro-checker were only

64 significant at GL23. There is no linkage disequilibrium between any loci, including two

65 pairs of loci located within single ESTs (GP340:GP63 and C1831:C1832). The p-values

66 resulting from tests of linkage disequilibrium for G340-GP63 and C1831-C1832 are

670.21071 and 0.42857 respectively; the adjusted p-value is 0.001786 . Using NCBI

68 BLASTn analysis, two sequences were identified in GenBank (accession numbers

69 AY485259 and AY496639) having homology with loci G340 and GP63. 
71 Acknowledgements

72 This project was supported by National Research Initiative Competitive Grant no. 2003-

73 35206-12834 from the USDA Cooperative State Research, Education, and Extension

74 Service and by a grant from the County of Barnstable Massachusetts, USA (both to

75 SBR).

76

77 References

78 Arnold, WS. 2001 Bivalve enhancement and restoration strategies in Florida, U.S.A.

79 Hydrobiologia, 465(1-3): 7-19

80

81 Goudet J (1995) FSTAT version1.2: a computer program to calculate Fstatistics. Journal

82 of Heredity, 86: 485-486. Version 2.9.3 available from

83 http://www.unil.ch/izea/softwares/fstat.html.

84

85 Kantety RV, La Rota M, Matthews DE, Sorrells ME. (2002) Data mining for simple

86 sequence repeats in expressed sequence tags from barley, maize, rice, sorghum and

87 wheat. Plant Molecular Biology. 48(5-6):501-510

88

89 National Marine Fisheries Service. 2004. Annual Commercial Landing Statistics.

90 [Online]. http://www.st.nmfs.gov/st1/commercial/landings/annual_landings.html 
92 Roberts SB. and Goetz, F.W. 2003. Expressed sequence tags analysis of genes expressed

93 in the bay scallop, Argopecten irradians. (Short Report) Biological Bulletin, 205: 227-

94228.

95

96 Temnykh S, DeClerck G, Lukashova A, Lipovich L, Cartinhour S, McCouch S (2001)

97 Computational and experimental analysis of microsatellites in rice (Oryza sativa $\mathrm{L})$ :

98 frequency, length variation, transposon associations, and genetic marker potential.

99 Genome Research, 11: 1441-1452.

100

101 van Oosterhout C, Hutchinson WF, Wills DPM, Shipley P (2004) Micro-checker:

102 software for identifying and correcting genotyping errors in mirosatellite data. Molecular 103 Ecology Notes, 4: 535-538.

104

105 Walsh PS, Metzger DA, and Higuchi R. 1991. Chelex 100 as a medium for simple

106 extraction of DNA for PCR-based typing from forensic material. Biotechniques, 10: 506107513. 


\begin{tabular}{|c|c|c|c|c|c|c|c|c|c|}
\hline $\begin{array}{c}\text { Locus } \\
(\text { Accession \#) }\end{array}$ & Primers & $\mathbf{T}_{\mathrm{an}}$ & SSR & $\begin{array}{l}\text { Size } \\
\text { (bp) }\end{array}$ & $\mathbf{N}_{\mathbf{a}}$ & $\mathbf{N}_{\mathrm{i}}$ & $\mathrm{H}_{\mathrm{o}}$ & $\mathbf{H}_{\mathrm{e}}$ & $\mathbf{P}_{\mathrm{HW}}$ \\
\hline $\begin{array}{c}\mathrm{M} 26 \\
(\mathrm{CV} 660848) \\
\end{array}$ & $\begin{array}{l}\text { F: CACTTTCAGCAGATATTCTTGAGG } \\
\text { R: TCCCATCCTCTCCTTCACAG }\end{array}$ & 55 & $(\mathrm{GAT})_{10}$ & 120 & 5 & 44 & 0.591 & 0.656 & 0.1938 \\
\hline $\begin{array}{c}\text { GL23 } \\
\text { (CV828452) } \\
\end{array}$ & $\begin{array}{l}\text { F: ATAAAACAGGCAAAGAGGCAC } \\
\text { R: TGCTTGGTGAATGGGGC }\end{array}$ & 55 & $(\mathrm{CA})_{11}$ & 132 & 5 & 20 & 0.25 & 0.649 & 0.0063 \\
\hline $\begin{array}{c}\text { S336 } \\
(\mathrm{CN783139)} \\
\end{array}$ & $\begin{array}{l}\text { F: GCGGAGGCAGATTCTTTCTTTTC } \\
\text { R: GGTCGTGGATTGTAAGCATTGTC }\end{array}$ & 54 & $(C A G)_{5}$ & 128 & 4 & 23 & 0.478 & 0.608 & 0.1375 \\
\hline 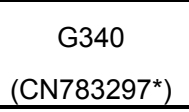 & $\begin{array}{l}\text { F: CGCTTGTGTTTTACGAGGAGAAGG } \\
\text { R: TGACGGGGTGTGATGTCTGACC }\end{array}$ & 53 & $(\mathrm{GAT})_{5}$ & 114 & 5 & 47 & 0.575 & 0.642 & 0.1625 \\
\hline $\begin{array}{c}\text { GP63 } \\
(\text { CK484125*) }\end{array}$ & $\begin{array}{l}\text { F: AACTTTTCCCTCATCGTGTCACC } \\
\text { R: CAGTCACAACTATCAACCTGCCC }\end{array}$ & 54 & $(\mathrm{CAG})_{5}$ & 223 & 4 & 20 & 0.600 & 0.522 & 0.2250 \\
\hline $\begin{array}{c}\text { N391 } \\
\text { (CN782436) }\end{array}$ & $\begin{array}{l}\text { F: TCATCGCCTCCACCTTCAG } \\
\text { R: GATCACACTTTGATTTGTCCTACG }\end{array}$ & 58 & $(A G)_{14} \mathrm{~A}(\mathrm{AG})_{5}$ & 243 & 4 & 22 & 0.591 & 0.720 & 0.0938 \\
\hline $\begin{array}{c}\text { C1831 } \\
(\mathrm{CK} 484157) \\
\end{array}$ & $\begin{array}{l}\text { F: CGAGTATCAATAGCCGAATCTAAGC } \\
\text { R: CCGTAGTTAGATCTCTGTTGGTAG }\end{array}$ & 52 & $(G G C)_{5}$ & 122 & 2 & 21 & 0.095 & 0.093 & 0.9625 \\
\hline $\begin{array}{c}\text { C1832 } \\
(\mathrm{CK} 484157) \\
\end{array}$ & $\begin{array}{l}\text { F: CAGTTATGGATCAGGCGGTAGAAG } \\
\text { R: GCGAGCGAGTACAACCTTAAAACAC }\end{array}$ & 55 & $(\mathrm{GTG})_{6}$ & 122 & 2 & 23 & 0.217 & 0.198 & 0.7813 \\
\hline
\end{tabular}

Table 1: EST-SSRs in the bay scallop (Argopecten irradians)

$\mathrm{T}_{\text {an }}$, annealing temperature; $\mathrm{N}_{\mathrm{a}}$, number of alleles; $\mathrm{N}_{\mathrm{i}}$, number of individuals assayed; $\mathrm{H}_{\mathrm{o}}$, observed heterozygosity; $\mathrm{H}_{\mathrm{e}}$, unbiased expected heterozygosity; $\mathrm{P}_{\mathrm{HW}}$, probability that genotype proportions conform to Hardy-Weinberg equilibrium. The adjusted value for significance (5\%) following Bonferroni corrections is 0.00625. Asterisk indicates that multiple bay scallop ESTs contain given loci. The accession number for the sequences each loci was originally characterized is listed. 